\title{
Dental microwear analysis in Gliridae (Rodentia): methodological issues and paleodiet inferences based on Armantomys from the Madrid Basin (Spain)
}

\author{
A. Oliver ${ }^{1 *}$, V. Hernández-Ballarín ${ }^{1}$, P. López-Guerrero, ${ }^{2,3}$, I. García-Paredes ${ }^{2,3}$, M. A. Álvarez- \\ Sierra $^{2,3}$, A. R. Gómez Cano ${ }^{2,3}$, B. A. García Yelo ${ }^{1,2}$, G.M. Alcalde ${ }^{1}$ P. Peláez-Campomanes ${ }^{1}$ \\ ${ }^{1}$ Museo Nacional de Ciencias Naturales-CSIC, C/ José Gutiérrez Abascal, 2, 28006 Madrid, Spain. \\ ${ }^{2}$ Departamento de Paleontología, Facultad de Ciencias Geológicas, Universidad Complutense de Madrid, \\ C/ Jose Antonio Novais, 2, 28040 Madrid, Spain. \\ ${ }^{3}$ Departamento de Geología Sedimentaria y Cambio Ambiental, Instituto de Geociencias IGEO (CSIC, UCM), \\ C/ José Antonio Novais, 2, 28040, Madrid, Spain.
}

e-mail addresses: adriana@mncn.csic.es (A.O., *corresponding author); verohernandez@mncn.csic.es (V.H.-B.); palomalopez@geo.ucm.es (.P.L.-G.);isgarpa@ geo.ucm.es (I.G.-P.); masierra@geo.ucm.es (M.A.A.-S.); argomez@geo.ucm.es (A.R.G.C);blancayelo@hotmail.com (B.A.G.Y.); paleogem@gmail.com;(G.M.A.);

$$
\text { mcnp177@mncn.csic.es (P.P.-C.) }
$$

Received: 3 October 2012 / Accepted: 4 December 2013 / Available online: 25 February 2014

\begin{abstract}
In the present study we analyze the microwear of the species included in the lineage Armantomys aragonensis-A. tricristatus of two samples from two middle Miocene localities from the Madrid Basin (El Cañaveral and Casa Montero). The methodological part of the study compares light stereomicroscope photographs from resin casts and Environmental Scanning Electron Microscope (ESEM) photographs from original material. Furthermore two regions of the tooth crown (the most lingual part of the anteroloph, and the most lingual part of the protoloph) and two homologous regions of first and second upper molars have been analyzed. The paleoecological part includes the results of the microwear analyses of the two species included in the lineage A. aragonensis-A. tricristatus. The replacement of $A$. aragonensis with A. tricristatus in the Madrid Basin occurred during the Middle Miocene Climate Transition (MMCT) and is marked by a change in dental morphology. Therefore, in order to infer changes in diet associated to a shift in the environment, we checked for correlations on microwear features between the two different morphologies of the species.

The two methodologies tested, ESEM on original teeth and light stereomicroscopy on resin casts, showed similar results on microwear analysis in the glirid Armantomys. Besides, both regions of the tooth crown and dental elements showed the same microwear patterns. The substitution of the species included in the lineage Armantomys aragonensis-A. tricristatus might not imply a change in diet.
\end{abstract}

Keywords: glirids, small-mammals, local biozone E, Aragonian, middle Miocene

Resumen

En el presente trabajo analizamos los patrones de microdesgaste de las especies incluidas en el linaje Armantomys aragonensis-A. tricristatus de dos muestras procedentes de dos yacimientos del Mioceno medio de la Cuenca de Madrid (El Cañaveral y Casa Montero). En la parte metodológica de este estudio se comparan fotografías de lupa binocular obtenidas a partir de moldes de resina y fotografías de microscopio electrónico de barrido ambiental (ESEM) a partir de material original. Además, se han analizado dos regiones de la corona dental (la zona más lingual del anterolofo y la zona más lingual del protolofo) y dos regiones homólogas del primer y segundo molar superiores. La parte paleoecológica del estudio incluye los resultados de los análisis de microdesgaste de las dos especies incluidas en el linaje A. aragonensis-A. tricristatus. El reemplazamiento de A. aragonensis por A. tricristatus en la Cuenca de Madrid tiene lugar durante la Transición Climática del Mioceno Medio (MMCT) y está marcado por un cambio en la morfología dental. Así, para inferir variaciones en la dieta asociados a un cambio en el ambiente, hemos estudiado la correlación de los patrones de microdesgaste entre las dos diferentes morfologías que presenta cada especie.

Las dos metodologías comparadas, ESEM en dientes originales y lupa binocular en moldes de resina, muestran resultados similares en los análisis del microdesgaste en el glírido Armantomys. Además, dos regiones de la corona dental y los dos elementos dentales muestran los mismos patrones de microdesgaste. La sustitución de las especies incluidas en el linaje Armantomys aragonensis-A. tricristatus podría no ir asociado a un cambio en la dieta. 


\section{Introduction}

Dental microwear analysis has become an important source to infer paleodiets of many extinct organisms. Besides, the use of diets inferred from microwear as environmental proxy has allowed reconstructing environmental conditions of particular areas (Lewis et al., 2000; Hopley et al., 2006; Merceron et al., 2007a; Ungar et al., 2007; DeMiguel et al., 2011).

Dental microwear analysis was originally developed and mainly applied to macro-mammals (e.g., Walker et al., 1978; Solounias et al., 1988; Solounias and Semprebon, 2002; Merceron et al., 2004; 2005; 2007b; Semprebon et al., 2004; Goillot et al., 2009; Peigné et al., 2009; DeMiguel et al., 2011), and more specifically to large mammalian herbivores. The methodologies were adapted to the teeth of modern and fossil rodents, resulting in several works which consider dental microwear as a good indicator of paleodiets in different rodent groups (e. g., Rensberger, 1978; Lewis et al., 2000; Nelson et al., 2005; Hopley et al., 2006; Townsend and Croft, 2008; Gomes Rodrigues et al., 2009; Firmat et al., 2010).

Despite the increase of such studies on rodents, there is only one dental microwear analysis applied to the family Gliridae (Hautier et al., 2009), a very important group in the European Miocene rodent faunas. The diversification of Gliridae and the occurrence of new dental morphologies began in the early Eocene and culminated in the late early Miocene. By then, they became one of the most abundant groups of rodents, probably due to an increase in niches occupied by this family (Daams and De Bruijn, 1995). The evolution of glirids towards a simpler dental pattern arose mainly in the Iberian Peninsula during the early Miocene, being especially abundant and/or diverse in the Spanish lower and middle Miocene small-mammal assemblages (García-Paredes et al., 2009).

This is the case of the genus Armantomys De Bruijn 1966, a relatively large Gliridae endemic to the Iberian Peninsula ranging from the late Oligocene to the late middle Miocene. It is characterized by a simple asymmetrical dental pattern composed by four strongly built ridges and relatively high crowned teeth, which is a unique character among the family. Daams (1990) recognized two lineages in this genus (see García-Paredes and van den Hoek Ostende, 2007, for comments about correct publication date of species described in that paper): the Armantomys bijmai-A. daamsi-A. parsani-A. jasperi lineage, which includes the smallest species, and the Armantomys aragonensis-A. tricristatus lineage characterized by large teeth, massive ridges, and the highest degree of hypsodonty among the Gliridae. There are some differences between the two successive species, Armantomys tricristatus differs from $A$. aragonensis by its: larger size, more inclined ridges, lack of the anteroloph in $\mathrm{P} 4$, metaloph-posteroloph connection in upper molars, and completely developed and isolated mesolophid and posterolophid in $\mathrm{m} 3$ (Daams, 1990; García-Paredes, 2006). Nevertheless, the particular dental morphology of both species has been interpreted as a highly specialized dentition adapted to feed on very tough and hard vegetation, which is related to an open and dry landscape (Daams and Van der Meulen, 1984).

The present study is focused on two samples of the successive species $A$. aragonensis- $A$. tricristatus from two middle Miocene localities sited in the Madrid Basin (Fig.1). The first species, A. aragonensis, is present in the older locality (El Cañaveral, Hernández-Ballarín et al., 2010) and A. tricristatus in the younger one (Casa Montero, López-Guerrero et al., 2007). Both localities belong to the local biozone $\mathrm{E}$ (middle Aragonian, middle Miocene; Van der Meulen et al., 2011, 2012), where previous studies pointed out differences in the small-mammal assemblages between the two fossil sites (Hernández-Ballarín et al., 2010; 2011), and might associate these changes with a context of changing environment.

We have applied a semiautomated image microwear analyses procedure to Armantomys from the Madrid Basin, in order to: 1) study the individual and assemblage variation on microwear features of this extinct genus and 2) infer the feeding habits, and assess its temporal variability along the Armantomys lineage. The present study consequently comprises two parts. The first one, mainly methodological, compares the two most used methodologies in microwear analysis (light stereomicroscope photographs from resin casts and Scanning Electron Microscope photographs from original material which, in our case, has been made in environmental mode without coating) and makes an attempt to check differences between different occlusal surfaces and dental elements. The second part includes the results of the microwear analyses of the two species included in the lineage $A$. aragonensis - A. tricristatus. The replacement of $A$. aragonensis by A.tricristatus in the Madrid Basin occurred during the Middle Miocene Climate Transition (MMCT) (Shackleton and Kennet, 1975; Zachos et al., 2001; Shevenell et al., 2004) and is marked by a change in dental morphology. Therefore, in order to infer changes in diet associated to a shift in the environment, we checked for correlations on microwear features between the two different morphologies of the species.

\section{Materials and methods}

The samples used to perform the study comprise cheek teeth of the genus Armantomys from two middle Aragonian (middle Miocene) localities (El Cañaveral and Casa Montero) sited in the Madrid Basin. Isolated molars and upper maxillas from the former and latter sites, respectively, were selected based on the good preservation of the occlusal surface. Specimens with advanced wear and unworn molars were rejected.

Microwear was measured on two areas of the occlusal surface of first and second upper molars: the most lingual part of the anteroloph, and the most lingual part of the protoloph (Fig. 2). These areas were selected because they provided a relatively large, prominent and flat surface to study microwear features. 


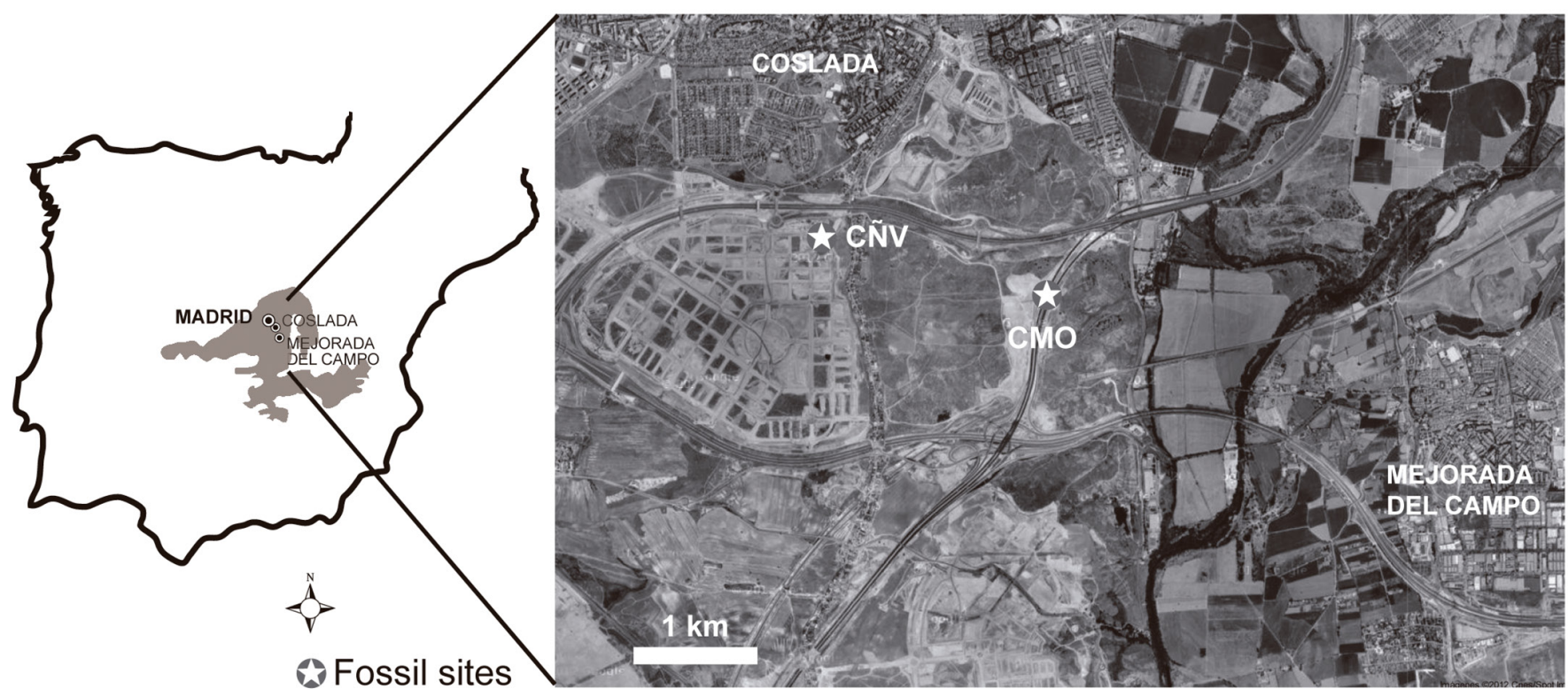

Fig. 1.- Map of the Iberian Peninsula showing the two middle Miocene localities from the Madrid Basin (El Cañaveral and Casa Montero). In grey Central Spanish Cenozoic basins where the Madrid Basin is included. CÑV: El Cañaveral; CMO: Casa Montero.

A square area of $0.01 \mathrm{~mm}^{2}$ was examined using ObjectJ (software Fiji-ImageJ 1.46i). Six microwear features were quantified: number of wide scratches (Nws), number of fine scratches (Nfs), number of large pits (Nlp), number of small pits (Nsp), and length and orientation of the scratches. Pits were differentiated from scratches on the basis of a width/ length ratio higher than 1/4 (Grine, 1986). Distinction between wide and fine features was settled at a maximum width of $5 \mu \mathrm{m}$ (Gomes Rodrigues et al., 2009). Features whose margins have been truncated by the edge of the square were also measured, avoiding possible biases when length and orientation of the scratches is taken into account. To avoid inter-observer errors only one observer has examined the photographs.

For the first part of the study, 13 photographs from Casa Montero (representing two different areas and two dental elements of four maxillas) and six photographs from El Cañaveral (representing three isolated teeth) were selected (see table 1 for details). "Ebalta" polyurethane resin casts were made following the protocol developed by Merceron et al. (2004; 2005) and adapted for small-mammals by Gomes Rodrigues et al. (2009). Low magnification light microscope photographs were taken with a Spot CCD camera (DFC 420, at a resolution of $2592 \times 1944$ pixels) connected to a light stereomicroscope (Leica M 165C), set at 100x. Besides, photographs of the original teeth were taken in the same areas with an Environmental Scanning Electron Microscope (ESEM) Fei, model Quanta 200, with backscattered electron detector. In order to have ESEM photographs of similar pixel size than those of the light stereomicroscope, an image resolution of 2048x 1886 pixels and a 200x magnification were selected (Fig. 3a, b).
Firstly, a comparison between photographs obtained from resin casts and from original teeth was done, in order to test whether both methodologies show comparable results. Nws, Nfs, Nlp and Nsp were analyzed. The ESEM photographs were selected for the following analysis. Two regions of the tooth crown (the most lingual part of the anteroloph, and the most lingual part of the protoloph) in first and second upper molars (Fig. 2) were compared to test whether there are significant differences in the microwear pattern between the two areas of the same molar. Furthermore, a comparison between homologous regions of both molars was carried out.

For the paleoecological part of the study, high magnification photographs (image resolution of 2048x1886 pixels and a 700x magnification) of the original teeth from the two localities were taken with an ESEM Fei, model Quanta 200, with backscattered electron detector (Fig. 3c, d). Ten photographs of each species (A. aragonensis and A. tricristatus), representing anterolophs and protolophs of first and second upper molars, from seven different specimens of each fossil site were selected. The variables Nws, Nfs, Nlp, Nsp, length and orientation of the scratches were analyzed. These comparisons have allowed to test if there are differences in the microwear patterns between both assemblages.

Univariate and multivariate statistical analyses were carried out with SPSS v. 11.5.1 (SPSS, 2002) and Past v. 2.14 (Hammer et al., 2001). Paired statistical analysis (Paired T-student and Wilcoxon tests) and Two-group permutation were applied for the comparison between ESEM and cast; anteroloph and protoloph; homologous areas of M1 and M2; and comparison of the length of the scratches between low and high magnification. For the paleoecological analyses, univariate statistical analyses (T-student and Mann-Whitney) and MANOVA were performed. 


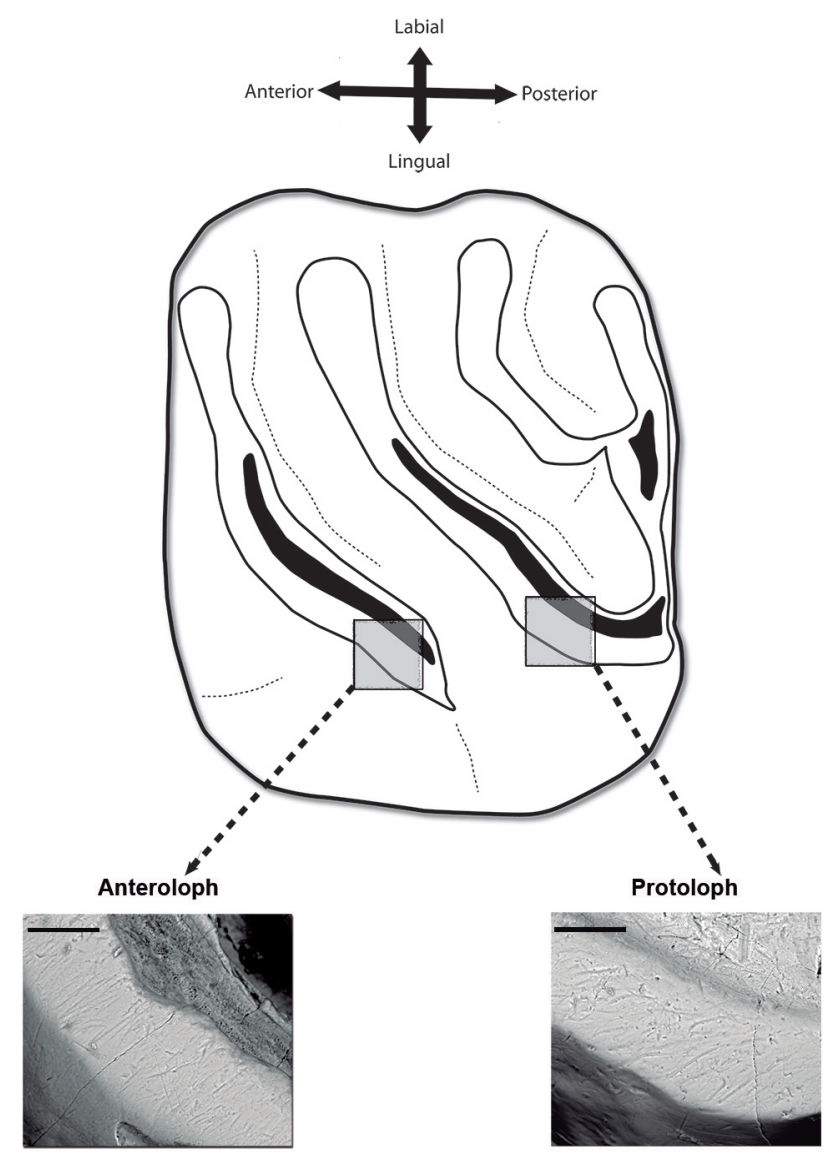

Fig. 2.- Localization of the anteroloph (left grey square) and the protoloph (right grey square) on the first and second upper molars of Armantomys. The graphic scale is $100 \mu \mathrm{m}$.

\section{Results and discussion}

The descriptive statistics are shown in table 1 and table 2 , and the statistical analyses in table 3 .

\subsection{ESEM-Original teeth versus Light Stereomicroscopy- Resin casts}

Studies of microwear, both in large as in small mammals, are mainly based in resin casts made from original teeth (Strait, 1993; Merceron et al., 2004; 2005; Scott et al., 2005; 2006; Gomes Rodrigues et al., 2009); whereas works directly based on original enamel are scarce (Walker et al., 1978; Rensberger, 1978; Lewis et al., 2000; Rivals and Deniaux, $2003 ; 2005)$. This difference is due to: first, specimen size limitations of ESEM, usually less than $50 \mathrm{~mm}$; second, availability of ESEM installations; and third, the requirement of coating each specimen in "classical SEM" studies, which is expensive. Therefore it became necessary to cast the original teeth in order to analyse them with light microscope. One of the aims of the present study is to test for differences in the results on microwear obtained with casts (analyzed under light stereomicroscopy) and original teeth (analyzed with ESEM) at similar image resolution (at similar pixel size).
For this purpose, univariate analyses were carried out to analyze the variables (Nws, Nfs, Nlp, Nsp) independently. Shapiro-Wilk tests were applied to assess whether the variables are normally distributed. The variables Nws, Nlp and Nsp do not fit to a normal distribution. Paired T-Student analyses (for normal distribution variables) and Wilcoxon test (non-normal distribution variables) were fulfilled to test significant differences between both methodologies. None of them showed significant values (table 3 ), except Nsp ( $p=$ $0.0002)$.

Multivariate analyses were applied to test for significant differences between ESEM and light stereomicroscope considering the variables all together (Nfs, Nws, Nlp and Nsp). Two-group permutation tests were carried out, after checking that the assumption of multivariate normal distribution is not satisfied. In this case, statistical analyses show significant differences $(p=0.0005)$ between both methods (Table 3 ). Several authors concluded that small pits (Nsp) were difficult to photograph under light stereromicroscope because of its high refractivity or the low resolution of the images (Nelson et al., 2005; Mihlbachler et al., 2012); other authors indicate that no direct relation between small pits and diet existed in rodents (Townsend and Croft, 2008; Gomes Rodrigues et al., 2009; Firmat et al., 2010). Furthermore, small pits in ESEM photographs might be underestimated because of their low contrast (see Fig. 3). The significant differences obtained on the multivariate test could be due to methodological limitations of both techniques. Therefore, following previous authors that removed this variable from their analysis, we have repeated the multivariate analysis excluding Nsp and the results indicate non-significant values $(\mathrm{p}=0.60)$ for the remaining variables (Nfs, Nws, and Nlp) (Table 3). The obtained results pointed out that there are no differences between these two methodologies of microwear analysis. Nevertheless, when comparing results with ESEM techniques, we detected between $48 \%$ and $80 \%$ more fine features (Nfs and Nsp) on ESEM photographs taken at high magnification than on those taken at low magnification (Table 1 and Table 2). In addition, the analyses showed significant differences in the fine scratches length between the two magnifications, being shorter at high magnification (see Tables 1 and 2). This could be explained because at low magnification the smallest scratches are not recognized, and therefore the average is biased towards larger sizes.

\subsection{Anteroloph versus protoloph and M1 versus M2 (homologous regions)}

The second methodological goal of this study was to test for significant differences on microwear between two regions in the same dental element and between two homologous areas of M1 and M2 of the glirid Armantomys.

As explained above, univariate methods were performed to analyze the variables (Nws, Nfs, Nlp, Nsp) independently. Shapiro-Wilk tests were applied to evaluate whether the 


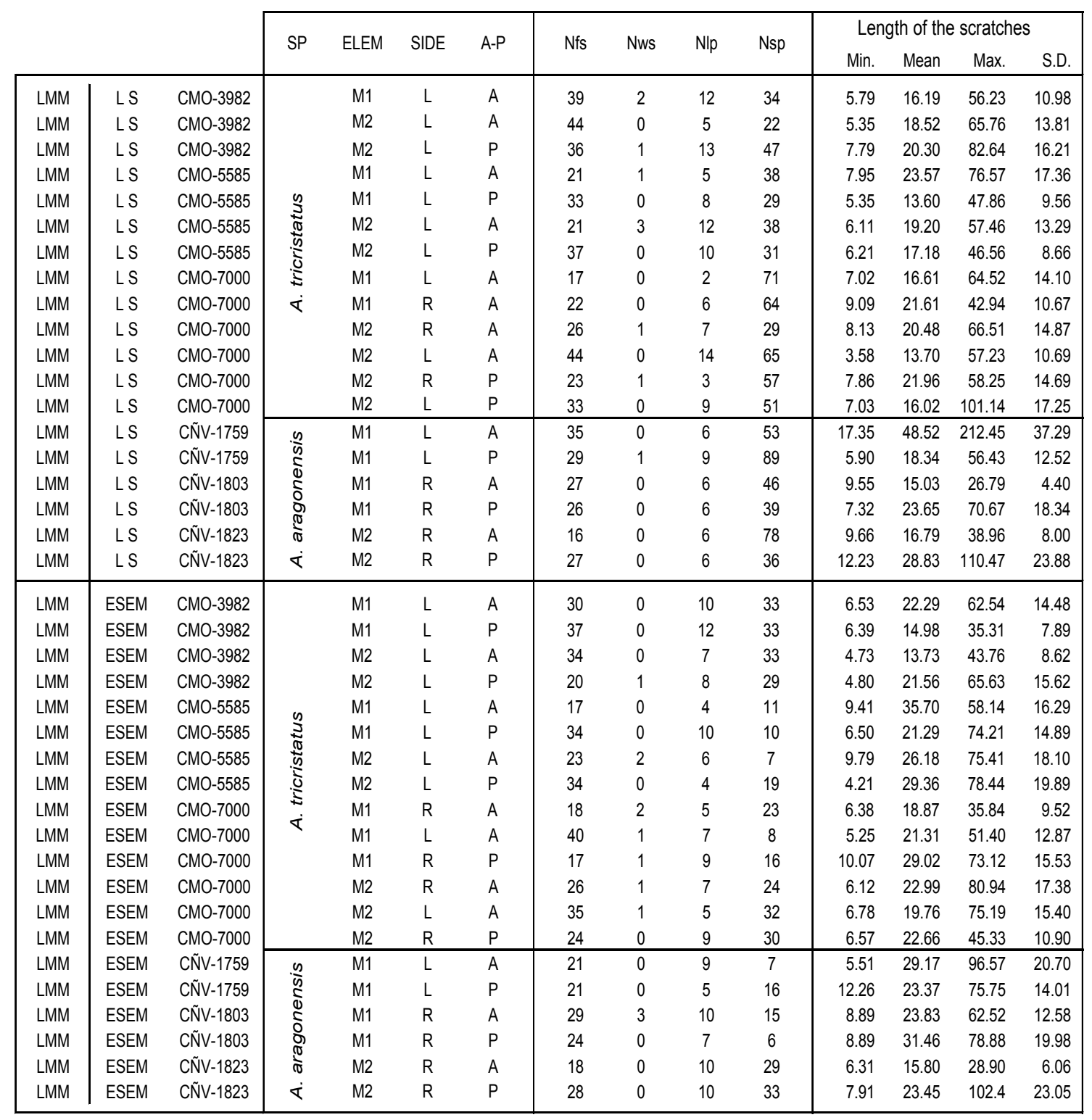

Table 1.-Dental microwear variables of the glirids Armantomys aragonensis from El Cañaveral and A. tricristatus from Casa Montero, at low magnification. LS: Light Stereomicroscope; ESEM: Environmental Scanning Electron Microscope; CÑV: El Cañaveral; CMO: Casa Montero; SP: Species; ELEM: Element; R: Right; L: Left; A: Anteroloph; P: Protoloph; Nfs: Number of fine scratches; Nws: Number of wide scratches; Nlp: Number of large pits; Nsp: Number of small pits; Min: Minimum length of the scratches; Mean: Mean length of the scratches; Max: Maximum length of the scratches; S.D.: Standard Deviation of the length of the scratches.

variables are normally distributed. Only Nws does not fit a normal distribution. Paired T-Student analyses (for variables with normal distribution) and Wilcoxon tests (for Nws) were performed to assess significant differences between microwear features on the lingual border of the anteroloph and the lingual border of the protoloph; and between the two homologous regions in the M1 and M2. All analyzed variables show non-significant differences between neither areas nor dental elements. For multivariate analyses Two-group permutation tests were applied resulting in non-significant differences (Table 3 ).

Gordon (1982) demonstrated that facet type and molar position are two of the most remarkable factors affecting variability in microwear pattern. Thus, he pointed out that mixing of functionally different facets increases the microwear variability because of biomechanical gradients along the tooth row. Contrary to Gordon, we have shown that both areas and both dental elements registered the same microwear pattern in Armantomys, suggesting that M1 and M2 entail the same biomechanical performance during the chewing. Furthermore, the use of either of the two elements or either of the two regions of the tooth allows us to increase sample size and to avoid biases caused by element misidentifications.

\subsection{Paleoecological analyses}

The microwear patterns of Armantomys from the localities studied here are characterized by high number of small 


\begin{tabular}{|c|c|c|c|c|c|c|c|c|c|c|}
\hline & \multirow{2}{*}{ ELEM } & \multirow{2}{*}{ A-P } & \multirow{2}{*}{ Nfs } & \multirow{2}{*}{ Nws } & \multirow{2}{*}{$\mathrm{Nlp}$} & \multirow{2}{*}{ Nsp } & \multicolumn{4}{|c|}{ Length of the scratches } \\
\hline & & & & & & & Min. & Mean & Max. & S.D. \\
\hline CMO-3982 & M1 & A & 93 & 1 & 3 & 57 & 3.68 & 15.65 & 60.11 & 12.97 \\
\hline CMO-3982 & M1 & $\mathrm{P}$ & 86 & 0 & 2 & 87 & 2.46 & 16.80 & 110.68 & 18.80 \\
\hline CMO-5580 & M1 & A & 80 & 0 & 4 & 114 & 1.75 & 9.80 & 70.32 & 10.00 \\
\hline CMO-5584 & M1 & P & 70 & 0 & 9 & 65 & 2.92 & 15.48 & 61.95 & 14.59 \\
\hline CMO-5585 & M2 & A & 67 & 0 & 5 & 63 & 2.90 & 12.42 & 67.86 & 12.13 \\
\hline CMO-5585 & M2 & $\mathrm{P}$ & 52 & 0 & 2 & 38 & 2.88 & 21.70 & 112.74 & 21.44 \\
\hline CMO-5627 & M1 & A & 71 & 0 & 3 & 89 & 2.07 & 13.55 & 109.23 & 15.44 \\
\hline CMO-5627 & M1 & P & 87 & 0 & 4 & 104 & 2.06 & 12.45 & 72.73 & 11.49 \\
\hline CMO-7000 & M1 & A & 67 & 1 & 1 & 49 & 2.64 & 16.58 & 71.62 & 15.71 \\
\hline CMO-7001 & M1 & P & 57 & 0 & 4 & 104 & 3.08 & 19.98 & 136.56 & 22.12 \\
\hline & & Mean & 73 & 0.2 & 3.7 & 77 & & & & \\
\hline \multirow{2}{*}{\multicolumn{2}{|c|}{$N=10$}} & S.D. & 13.32 & 0.42 & 2.21 & 26.07 & & & & \\
\hline & & C.V. & 18.24 & & 59.82 & 33.85 & & & & \\
\hline CÑV-1170 & M2 & A & 59 & 0 & 3 & 120 & 2.74 & 12.83 & 67.90 & 13.77 \\
\hline CÑV-1170 & M2 & $\mathrm{P}$ & 65 & 0 & 4 & 100 & 2.74 & 10.78 & 40.88 & 8.23 \\
\hline CÑV-1171 & M2 & A & 66 & 0 & 8 & 77 & 2.41 & 10.60 & 56.38 & 9.65 \\
\hline CÑV-1759 & M1 & A & 95 & 0 & 5 & 92 & 2.05 & 12.81 & 116.97 & 13.60 \\
\hline CÑV-1803 & M1 & $\mathrm{P}$ & 96 & 0 & 4 & 92 & 3.00 & 15.64 & 76.80 & 14.46 \\
\hline CÑV-1821 & M2 & A & 51 & 0 & 5 & 59 & 4.79 & 14.70 & 52.58 & 10.83 \\
\hline CÑV-1821 & M2 & $P$ & 69 & 0 & 6 & 79 & 4.57 & 12.65 & 89.61 & 13.33 \\
\hline CÑV-1823 & M2 & $\mathrm{P}$ & 55 & 0 & 6 & 76 & 2.73 & 14.68 & 73.76 & 16.36 \\
\hline CÑV-1826 & M2 & A & 43 & 1 & 5 & 77 & 2.94 & 14.31 & 52.85 & 12.69 \\
\hline CÑV-1826 & M2 & $P$ & 83 & 0 & 5 & 94 & 2.79 & 12.88 & 57.91 & 10.85 \\
\hline & & Mean & 68.2 & 0.1 & 5.1 & 86.6 & & & & \\
\hline \multirow{2}{*}{\multicolumn{2}{|c|}{$N=10$}} & S.D. & 18 & 0.32 & 1.37 & 16.75 & & & & \\
\hline & & C.V. & 26.39 & & 26.87 & 19.33 & & & & \\
\hline
\end{tabular}

Table 2.-Dental microwear variables of the glirids Armantomys aragonensis from El Cañaveral and A. tricristatus from Casa Montero, at high magnification (700x). LS: Light Stereomicroscope; ESEM: Environmental Scanning Electron Microscope; CÑV: El Cañaveral; CMO: Casa Montero; SP: Species; ELEM: Element; A: Anteroloph; P: Protoloph; Nfs: Number of fine scratches; Nws: Number of wide scratches; Nlp: Number of large pits; Nsp: Number of small pits; Min: Minimum length of the scratches; Mean: Mean length of the scratches; Max: Maximum length of the scratches; S.D.: Standard Deviation of the length of the scratches; C.V.: Coefficient of Variation.

\begin{tabular}{|c|c|c|c|c|c|c|c|c|c|c|}
\hline & & & & & ARIAT & & & MULTIV & RIATE & \\
\hline & & $\mathrm{N}$ & Feature & Z & $\mathrm{t}$ & $\mathrm{df}$ & $\mathbf{p}$ & Feature & $\mathrm{MD}$ & $\mathrm{p}$ \\
\hline \multirow{3}{*}{ LMM } & $\begin{array}{l}\text { ESEM from original material- } \\
\text { LS from casts }\end{array}$ & 38 & $\begin{array}{l}\text { Nfs } \\
\text { Nws } \\
\text { Nlp } \\
\text { Nsp }\end{array}$ & $\begin{array}{l}-0.3178 \\
-0.0712 \\
-3.6632\end{array}$ & 1.67 & 18 & $\begin{array}{l}0.1129 \\
0.7507 \\
0.9432 \\
\mathbf{0 . 0 0 0 2}\end{array}$ & $\begin{array}{l}\text { Nfs, Nws, NIp, Nsp } \\
\text { Nfs, Nws, NIp }\end{array}$ & $\begin{array}{l}4.39 \\
0.21\end{array}$ & $\begin{array}{l}\mathbf{0 . 0 0 0 5} \\
0.6015\end{array}$ \\
\hline & Anteroloph-Protoloph & 20 & $\begin{array}{l}\text { Nfs } \\
\text { Nws } \\
\text { Nlp } \\
\text { Nsp }\end{array}$ & -1.5110 & $\begin{array}{l}-0.03 \\
-0.97 \\
-0.65\end{array}$ & $\begin{array}{l}9 \\
9 \\
9\end{array}$ & $\begin{array}{l}0.9793 \\
0.1308 \\
0.3582 \\
0.5333\end{array}$ & Nfs, Nws, Nlp, Nsp & 0.69 & 0.5825 \\
\hline & M1-M2 & 14 & $\begin{array}{l}\text { Nfs } \\
\text { Nws } \\
\text { Nlp } \\
\text { Nsp }\end{array}$ & -0.3780 & $\begin{array}{r}-0.13 \\
\\
1.36 \\
-1.44\end{array}$ & $\begin{array}{l}6 \\
6 \\
6\end{array}$ & $\begin{array}{l}0.9030 \\
0.7055 \\
0.2214 \\
0.1988\end{array}$ & Nfs, Nws, NIp, Nsp & 1.49 & 0.479 \\
\hline HMM & A. aragonensis -A.tricristatus & 20 & $\begin{array}{l}\text { Nfs } \\
\text { Nws } \\
\text { Nlp } \\
\text { Nsp }\end{array}$ & -0.6104 & $\begin{array}{r}0.68 \\
-1.70 \\
-0.98\end{array}$ & $\begin{array}{l}18 \\
\\
15 \\
18\end{array}$ & $\begin{array}{l}0.5064 \\
0.5416 \\
0.1096 \\
0.3402\end{array}$ & Nfs, Nws, NIp, Nsp & & 0.3953 \\
\hline
\end{tabular}

Table 3.- Univariate and multivariate statistical analyses at low and at high magnification for the following comparisons: 1. ESEM photographs from original material and Light Stereomicroscopy photographs from resin casts. 2. Comparison of dental facets of the same tooth (Anteroloph-Protoloph). 3. Comparison of homologous regions of different teeth (M1-M2). 4. Comparisons of species (A. aragonensis-A. tricristatus). LMM: Low Magnification Microwear; HMM: High Magnification Microwear; ESEM: Environmental Scanning Electron Microscope; LS: Light Stereomicroscope; N : Number of specimens; Nfs: Number of fine scratches; Nws: Number of wide scratches; Nlp: Number of large pits; Nsp: Number of small pits ; Z: Non-parametric test value; t: T-student value; df: Degree of Freedom; p: Significance Value ; MD: Mahalanobis Distance. 


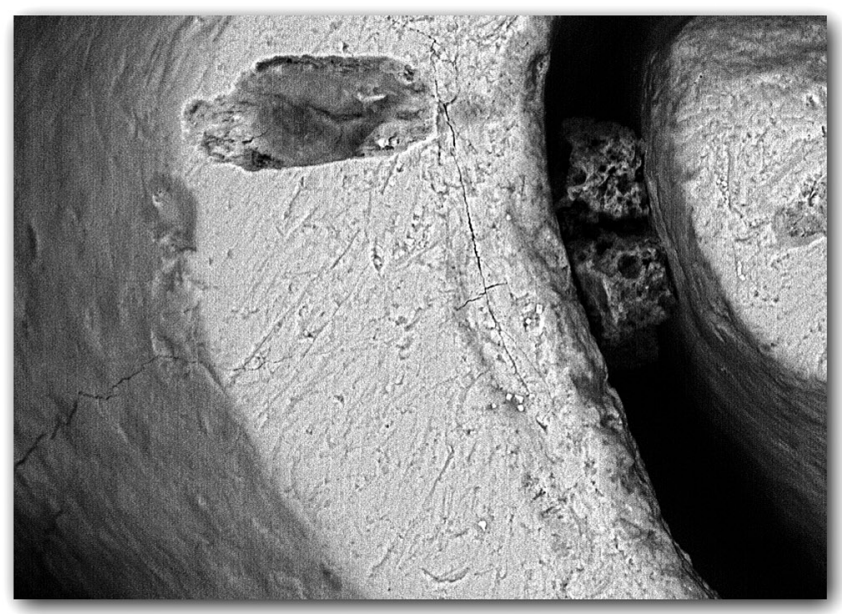

A

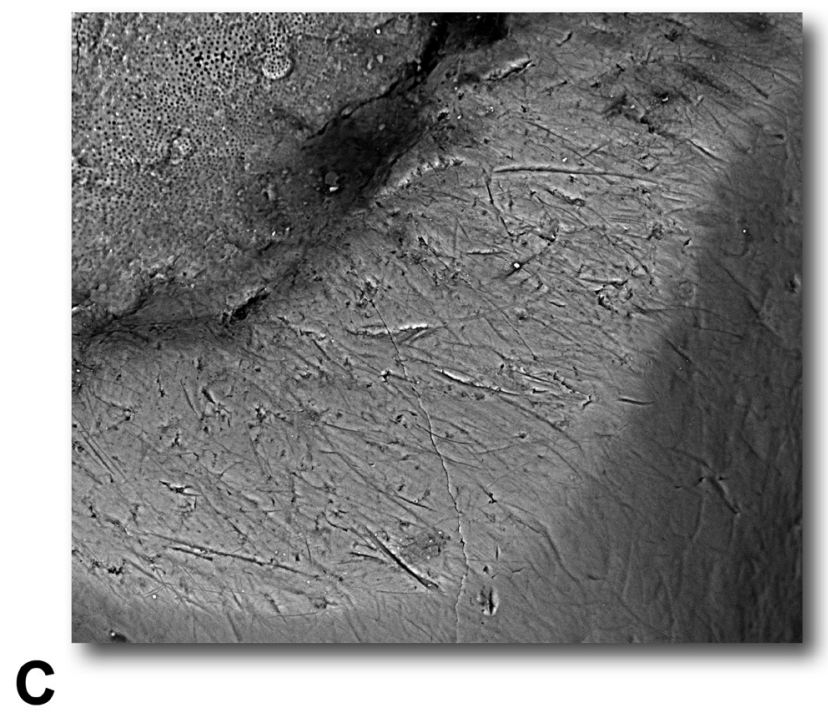

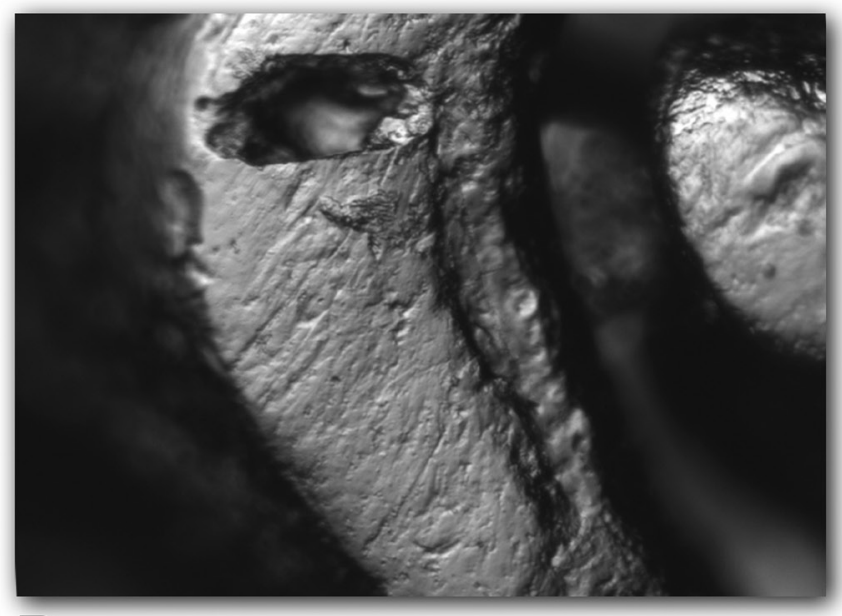

B

\section{$0.1 \mathrm{~mm}$}

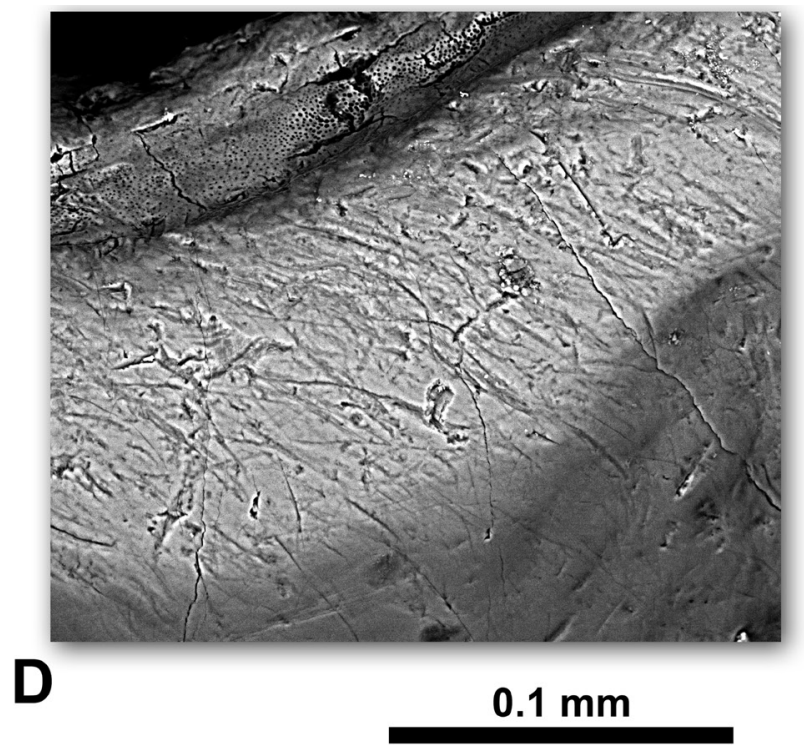

Fig 3.- Photographs of first and second upper molars of the protoloph of Armantomys aragonensis from El Cañaveral and A. tricristatus from Casa Montero. Comparison of the different methodologies used in the present work. A: CÑV-1823, right M2, ESEM photograph, (low magnification). B: $\mathrm{CN} V-1823$, right M2, light microscope photograph from resin cast (low magnification). C: CÑ -1803, right M1, ESEM photograph (high magnification). D: CMO-5627, right M1, ESEM photograph (high magnification). Scale bar equals $0.1 \mathrm{~mm}$ in both cases.

pits and fine scratches. According to Gomes Rodrigues et al. (2009) the high amount of the latter indicates an ingestion of large volume of grass, where the hard items would be responsible for these features. Furthermore, they added that species presenting high number of fine scratches occupy open areas as grasslands, where dust is abundant. Other studies also suggested that exogenous particles as dust, are also responsible for the large number of parallel striations, being not exclusively attributed to phytholiths alone (Gordon, 1982; Kay and Covert, 1983; Teaford, 1988; Ungar et al., 1995; Sanson et al., 2007). The dentition of the lineage Armantomys aragonensis-A. tricristatus has been interpreted as an adaptation to feed on very tough and hard vegetation available in open and dry landscapes (Daams and Van der Meulen, 1984) compatible with the idea that both dust and phytoliths from grass would be responsible for fine scratches. Hypsodont teeth in rodents were firstly interpreted by several authors as associated to abrasive diets dominated by grass (Kay and Madden, 1997; Vianey-Liaud, 1991; Williams and Kay, 2001). Nevertheless, other authors suggest that a hypsodont dentition does not necessarily restrict an animal to abrasive food, but provides wider dietary niches allowing for a more generalized diet (Jernvall and Fortelius, 2002; Feranec, 2003; Hopley et al., 2006). This more generalized diet of Armantomys based on the hypsodonty might be also supported by the fact that the high proportions of small pits could be correlated to the ingestion of soft seeds (Gliwicz, 1987; Gomes Rodrigues et al., 2009). Other authors (Solounias and Semprebon, 2002; Semprebon and Rivals, 2010) related, in ungulates, the heavy pitting with dry habitats where dust and grit are normally coating the vegetation. Nevertheless, this correlation has not been checked in other small mammal groups like rodents. Be- 
sides, according to the number of large pits, the consumption of insects cannot be rejected (Strait, 1993; Gomes Rodrigues et al., 2009). Therefore, our results might indicate a lessspecialized herbivore diet for Armantomys than previously thought.

A comparative analysis between the two species of dormouse from the Madrid Basin has been carried out in order to determine whether the microwear pattern of Armantomys varies through time. To perform this analysis we chose ESEM photographs at high magnification based on, firstly, the use of original material avoiding possible biases that might occur during casting, and secondly, the use of high magnification leads to better recognition of small microwear structures.

The univariate analyses indicated that Nfs, Nlp and Nsp are normally distributed variables, whereas Nws does not. Thus, a T-student test was applied to the first three variables and a Mann-Whitney test to the latter one. As for multivariate analyses a One-way MANOVA was applied. Neither the univariate nor the multivariate reveals significant differences (Table 3). These results indicate that there are non-significant differences on number of microwear features that could be correlated to the replacement of the species.

According to several authors microwear features can vary within a species, within a population or even along the life of the animal because of geographical and seasonal variations in diet (Walker et al., 1978). Further studies proved that microwear features are created and obliterated within 24 hours, in such wise that pits and scratches analyzed reflect mainly the most recent food items consumed (Teaford and Oyen, 1989). Based on those studies, the relatively low variation on microwear patterns observed on the Armantomys species (showing a high proportion of fine scratches and pits) may be interpreted as an indication that Armantomys had a diet of low seasonality.

\section{Conclusions}

The present study demonstrates that low-magnification ESEM photographs from original teeth and resin casts analyzed with light stereomicroscope reveal similar values on microwear analyses in the glirid Armantomys. Despite both methodologies show comparable results, we preferred ESEM high-resolution photographs for paleoecological comparisons. Our results indicated that both dental elements (first and second upper molars), and both regions of the tooth crown (the most lingual part of the anteroloph, and the most lingual part of the protoloph) showed the same microwear patterns. The paleoecological study performed indicates that Armantomys might have a less-specialized herbivore diet than previously thought (grass, soft seeds, insects...) and probably without seasonal variation. It also allows us to conclude that there are non-significant differences in microwear between the two species of Armantomys included in the study. That points out that there are no dietary changes associated to the substitution of the species included in the lineage Armantomys aragonensis- $A$. tricristatus.

\section{Acknowledgements}

We thank the Evo-Devo of Vertebrate dentition from the IGFL (Lyon), and G. Merceron (UCBL1) for his help and assistance. We also would like to thank the referees (F. Rivals and H. Gomes Rodrigues) for their comments on the manuscript. We acknowledge financial support by the Spanish MICINN projects CGL2008-04200/BTE, CGL200805813-C02-01/BTE， CGL2010-21672， CGL2011-28877, CGL2011-25754, and Research Group UCM-BSCH-910607. $\mathrm{AO}$ and BAGY have a FPU predoctoral contracts; VH-B has a FPI predoctoral contract; PL-G has a UCM predoctoral contract; and IG-P has a JAE-Doc contract (CSIC program "Junta para la Ampliación de Estudios"), co-funded by the European Social Fund.

\section{References}

Daams, R. (1990): Hypsodont Myomiminae (Gliridae, Rodentia) from the Miocene and the Oligocene-Miocene boundary interval of Spain. Scripta Geologica 95, 1-62.

Daams, R., van der Meulen, A. J. (1984): Paleoenvironmental and paleoclimatic interpretation of micromammal faunal successions in the upper Oligocene and Miocene of north central Spain. In: J. Meulenkamp (ed.), Paleoenvironnements continentaux en Méditerrannée au Néogène et évolution paléoclimatique. Paleobiologie Continentale. Faculté des sciences, Laboratoire de paléobotanique, Montpellier: 241-257.

Daams, R., de Bruijn, H. (1995): A classification of the Gliridae (Rodentia) on the basis of dental morphology. Hystrix (n.s.) 6 (1-2), 3-50. doi: 10.4404/hystrix-6.1-2-4015.

DeMiguel, D., Azanza, B., Morales, J. (2011): Paleoenvironments and paleoclimate of the Middle Miocene of central Spain: A reconstruction from dental wear of ruminants. Palaeogeography Palaeoclimatology Palaeoecology 302, 452-463. doi: 10.1016/j.palaeo.2011.02.005.

De Bruijn, H. (1966). Some new Miocene Gliridae (Rodentia, Mammalia) from the Calatayud area (prov. Zaragoza, Spain). I. Proceedings of the Koninklijke Nederlandse Akademie Van Wetenschappen, Series B 69(1), 58-71.

Feranec, R. S. (2003): Stable isotopes, hypsodonty, and the paleodiet of Hemiauchenia (Mammalia: Camelidae): a morphological specialization creating ecological generalization. Paleobiology 29, 230-242. doi: 10.1666/0094-8373/03/2902-0006.

Firmat, C., Gomes Rodrigues, H., Renaud, S., Claude, J., Hutterer, R., Garcia-Talavera, F., Michaux, J. (2010): Mandible morphology, dental microwear, and diet of the extinct giant rats Canariomys (Rodentia: Murinae) of the Canary Islands (Spain). Biological Journal of the Linnean Society 101, 28-40. doi: 10.1111/j.1095-8312.2010.01488.x.

García-Paredes, I. (2006): Patrones evolutivos de los Gliridae (Rodentia, Mammalia) del Mioceno inferior y medio del área tipo del Aragoniense (Cuenca de Calatayud-Montalbán). Ph.D. Thesis, Universidad Complutense de Madrid, Madrid: 676 p.

García-Paredes, I., van den Hoek Ostende, L. W. (2007): A nomenclatural note on the Miocene dormouse Quercomys parsani Daams, 1991. Contributions to Zoology 76, 205-206.

García-Paredes, I., Peláez-Campomanes, P., Álvarez Sierra, M. A. (2009): Gliridae (Rodentia, Mammalia) with a simpe dental pattern: 
a new genus and new species form the European Early and Middle Miocene. Zoological Journal of the Linnean Society 157, 622-652. doi: 10.1111/j.1096-3642.2009.00527.x

Gliwicz, J. (1987): Niche Segregation in a rodent community of African dry savanna. Journal of Mammalogy 68, 169-172.

Goillot, C., Blondel, C., Peigne, S. (2009): Relationships between dental microwear and diet in Carnivora (Mammalia): implications for the reconstruction of the diet of extinct taxa. Palaeogeography Palaeoclimatology Palaeoecology 271, 13-23. doi: 10.1016/j.palaeo.2008.09.004.

Gomes Rodrigues, H., Merceron, G., Viriot, L. (2009): Dental microwear patterns of extant and extinct Muridae (Rodentia, Mammalia): ecological implications. Naturwissenschaften 96, 537-542. doi: 10.1007/s00114-008-0501-x.

Gordon, K. D. (1982): A study of microwear on chimpanzee molars: Implications for dental microwear analysis. American Journal of Physical Anthropology 59, 195-215. doi: 10.1002/ajpa.1330590208.

Grine, F. E. (1986): Dental evidence for dietary differences in Australopithecus and Paranthropus: a quantitative analysis of permanent molar microwear. Journal of Human Evolution 15, 783-822. doi: 10.1016/S0047-2484(86)80010-0.

Hammer, O., Harper, D. A. T., Ryan, P. D. (2001): Past: paleontological statistics software package for education and data analysis. Palaeontologia Electronica 4, 1-9.

Hautier, L., Bover, P., Alcover, J.A., Michaux, J. (2009): Mandible morphometrics, dental microwear pattern, and palaeobiology of the extinct Balearic dormouse Hypnomys morpheus. Acta Palaeontologica Polonica 54, 181-194. doi: 10.4202/app.2008.0001.

Hernández-Ballarín, V., Oliver, A., García-Paredes, I., Peláez-Campomanes, P. (2010): Estudio preliminar de la fauna de roedores del yacimiento mioceno de El Cañaveral (Madrid, España). Cidaris 30, $151-153$

Hernández-Ballarín, V., Oliver, A., Pelaez-Campomanes, P. (2011): Revisión de las asociaciones de mamíferos del tránsito Aragoniense medio y superior de la Cuenca de Madrid. In: A. Pérez-García, F. Gascó, J. M. Gasulla, F. Escaso (eds.), Viajando a Mundos Pretéritos. Ayuntamiento de Morella, Morella (Castellón): 173-182.

Hopley, P. J., Latham, A. G., Marshall, J. D. (2006): Palaeoenvironments and palaeodiets of mid-Pliocene micromammals from Makapansgat Limeworks, South Africa: A stable isotope and dental microwear approach. Palaeogeography Palaeoclimatology Palaeoecology 233, 235-251. doi: 10.1016/j.palaeo.2005.09.011.

Jernvall, J., Fortelius, M. (2002): Common mammals drive the evolutionary increase of hypsodonty in the Neogene. Nature 417, 538-540. doi: $10.1038 / 417538$ a.

Kay, R. F., Covert, H. H. (1983): True grit: A microwear experiment. American Journal of Physical Anthropology 61, 33-38. doi: 10.1002/ ajpa.1330610104.

Kay, R. F., Madden, R. H. (1997): Mammals and rainfall: Paleoecology of the middle Miocene at La Venta (Colombia, South America). Journal of Human Evolution 32, 161-199. doi:10.1006/jhev.1996.0104.

Lewis, P. J., Gutierrez, M., Johnson, E. (2000): Ondatra zibethicus (Arvicolinae, Rodentia) dental microwear patterns as a potential tool for palaeoenvironmental reconstruction. Journal of Archaeological Science 27, 789-798. doi: 10.1006/jasc.1999.0502.

López Guerrero, P., Oliver Pérez, A., Álvarez Sierra, M. A., García-Paredes, I., van den Hoek Ostende, L. W., Peláez-Campomanes de Labra, P. (2007): Paleontología del yacimiento de vertebrados Aragoniense de Casa Montero (Madrid). In: O. Cambra-Moo, C. Martínez-Pérez, B. Chamero, F. Escaso, S. de Esteban Trivigno, J. Marugán-Lobón (eds.). Cantera Paleontológica. Diputación Provincial de Cuenca, Cuenca, 247-254.

Merceron, G., Blondel, C. Brunet, M., Sen, S., Solounias, N., Viriot, L. Heintz, E. (2004): The Late Miocene paleoenvironment of Afghani- stan as inferred from dental microwear in artiodactyls. Palaeogeography Palaeoclimatology Palaeoecology 207, 143-163. doi: 10.1016/j. palaeo.2004.02.008.

Merceron, G., Blondel, C., De Bonis, L., Koufos, G. D., Viriot L. (2005): A new method of dental microwear analysis: Application to extant primates and Ouranopithecus macedoniensis (Late Miocene of Greece): Palaios 20, 551-561. doi: 10.2110/palo.2004.p04-17.

Merceron, G., Blondel, C., Viriot, L., Koufos, G. D., De Bonis, L. (2007a): Dental microwear analysis of bovids from the Vallesian (late Miocene) of Axios Valley in Greece: reconstruction of the habitat of Ouranopithecus macedoniensis (Primates, Hominoidea). Geodiversitas 29 (3), 421-433.

Merceron, G., Schulz, E., Kordos, L., Kaiser, T. M. (2007b): Paleoenvironment of Dryopithecus brancoi at Rudabanya, Hungary: Evidence from dental meso- and micro-wear analyses of large vegetarian mammals. Journal of Human Evolution 53, 331-349. doi: 10.1016/j. jhevol.2007.04.008.

Mihlbachler, M. C, Beatty, B. L, Caldera-Siu, A., Chan, D., Lee, R. (2012): Error rates and observer bias in dental microwear analysis using light microscopy. Palaeontologia Electronica 15, 1-22. doi: 10.1002/sca.4950240307.

Nelson, S., Badgley, C., Zakem, E. (2005): Microwear in modern squirrels in relation to diet. Palaeontologia Electronica 8, 1, 14A.

Peigné, S., Goillot, C., Germonpre, M., Blondel, C., Bignon, O., Merceron, G. (2009): Predormancy omnivory in European cave bears evidenced by a dental microwear analysis of Ursus spelaeus from Goyet, Belgium. Proceedings of the National Academy of Sciences of the United States of America 106, 15390-15393. doi: 10.1073/ pnas.0907373106.

Rensberger, J. M. (1978): Scanning electron microscopy of wear and occlusal events in some small herbivores. In: P. M. Butler, K. A. Joysey (eds.) Development, function and evolution of teeth. Academic Press. New York: 415-438 .

Rivals, F., Deniaux, B. (2003). Dental microwear analysis for investigating the diet of an argali population (Ovis ammon antiqua) of midPleistocene age, Caune de l'Arago cave, eastern Pyrenees, France. Palaeogeography Palaeoclimatology Palaeoecology 193, 443-455. doi:10.1016/S0031-0182(03)00260-8.

Rivals, F., Deniaux, B. (2005). Investigation of human hunting seasonality through dental microwear analysis of two Caprinae in late Pleistocene localities in Southern France. Journal of Archaeological Science 32, 1603-1612. doi:10.1016/j.jas.2005.04.014.

Sanson, G. D., Kerr, S. A., Gross, K. A. (2007): Do silica phytoliths really wear mammalian teeth? Journal of Archaeological Science 34, 526-531. doi:10.1016/j.jas.2006.06.009.

Scott, R. S., Ungar, P. S., Bergstrom, T. S., Brown, C. A., Grine, F. E., Teaford, M. F., Walker, A. (2005): Dental microwear texture analysis shows within-species diet variability in fossil hominins. Nature 436, 693-695.

Scott, R. S., Ungar, P. S., Bergstrom, T. S., Brown, C. A., Childs, B. E., Teaford, M. F., Walker, A. (2006): Dental microwear texture analysis: technical considerations. Journal of Human Evolution 51, 339-349.

Semprebon, G. M., Godfrey, L. R., Solounias, N., Sutherland, M. R., Jungers, W. L. (2004): Can low-magnification stereomicroscopy reveal diet? Journal of Human Evolution 47, 115-144. doi:10.1016/j. jhevol.2004.06.004.

Semprebon, G. M., Rivals, F. (2010). Trends in the paleodietary habits of fossil camels from the Tertiary and Quaternary of North America. Palaeogeography Palaeoclimatology Palaeoecology 295, 131-145. doi:10.1016/j.palaeo.2010.05.033.

Shackleton, N. J., Kennett, J. P. (1975): Paleotemperature history of the Cenozoic and the initiation of Antarctic glaciation: oxygen and carbon isotope analyses in DSDP sites 277, 279, and 281. In: J. P. Kennett, R. E. Houtz (eds.), Initial Reports of the Deep Sea Drilling Project 29. 
U.S. Government Printing Office, Washington: 743-755. doi:10.2973/ dsdp.proc.29.117.1975.

Shevenell, A. E., Kennett, J. P., Lea, D. W. (2004). Middle Miocene Southern Ocean cooling and Antarctic cryosphere expansion. Science 305 (5691), 1766-1770. doi:10.1126/science.1100061.

Solounias, N., Semprebon, G. (2002). Advances in the reconstruction of ungulate ecomorphology with application to early fossil equids. American Museum Novitates 3366, 1-49. doi: http://dx.doi. org/10.1206/0003-0082(2002)366<0001:AITROU>2.0.CO;2.

Solounias, N., Teaford, M., Walker, A. (1988): Interpreting the diet of extinct ruminants: The Case of a Non-Browsing Giraffid. Paleobiology $14,287-300$.

SPSS. 2002. Statistical Package for the Social Sciences for Windows, Rel. 11.5.1. SPSS Inc., Chicago.

Strait, S. G. (1993): Molar Microwear in Extant Small-Bodied Faunivorous Mammals - an Analysis of Feature Density and Pit Frequency. American Journal of Physical Anthropology 92, 63-79. doi:10.1002/ ajpa.1330920106.

Teaford, M. F. (1988): A Review of Dental Microwear and Diet in Modern Mammals. Scanning Microscopy 2, 1149-1166.

Teaford, M. F., Oyen, O. J. (1989): Invivo and Invitro turnover in dental microwear. American Journal of Physical Anthropology 80, 447-460.

Townsend, K. E. B., Croft, D. A. (2008): Enamel microwear in caviomorph rodents. Journal of Mammalogy 89, 730-743. doi:10.1644/06MAMM-A-336R1.1.

Ungar, P. S., Teaford, M. F., Glander, K. E., Pastor, R. F. (1995): Dust Accumulation in the Canopy - a Potential Cause of Dental Microwear in Primates. American Journal of Physical Anthropology 97, 93-99. doi:10.1002/ajpa.1330970202.
Ungar, P. S., Merceron, G., Scott, R. S. (2007): Dental microwear texture analysis of Varswater bovids and early pliocene paleoenvironments of Langebaanweg, western cape province, South Africa. Journal of Mammalian Evolution 14(3), 163-181. doi:10.1007/s10914-0079050-x.

Van der Meulen, A. J., García-Paredes, I., Álvarez Sierra, M. A., Van den Hoek Ostende, L. W., Hordijk, K., Oliver, A., López-Guerrero, P., Hernández-Ballarín, V., Peláez-Campomanes, P. (2011): Biostratigraphy or Biochronology? Lessons from the Early and Middle Miocene small Mammal events in Europe. Geobios 44(2-3), 309-321. doi:10.1016/j.geobios.2010.11.004.

Van der Meulen, A. J., García-Paredes, I., Álvarez Sierra, M. A., Van den Hoek Ostende, L. W., Hordijk, K., Oliver, A., Peláez-Campomanes, P. (2012): Updated Aragonian biostratigraphy: Small Mammal distribution and its implications for the Miocene European Chronology. Geologica Acta 10(2), 1-24. doi:10.101344/105.000001710.

Vianey-Liaud, M. (1991): Late Eocene and Oligocene Rodents from Europe as Indicators of Their Environment. Palaeogeography Palaeoclimatology Palaeoecology 85, 15-28.

Walker, A., Hoeck, H. N., Perez, L. (1978): Microwear of mammalian teeth as an indicator of diet. Science 201, 908-910. doi:10.1126/science. 684415.

Williams, S. H., Kay, R. F. (2001): A comparative test of adaptive explanations for hypsodonty in ungulates and rodents. Journal of Mammalian Evolution 8, 207-229.

Zachos, J., Pagani, M., Sloan, L., Thomas, E., Billups, K. (2001): Trends, rhythms, and aberrations in global climate 65 ma to present. Science 292, 686-693. doi:10.1126/science.1059412. 